University of Nebraska - Lincoln

DigitalCommons@University of Nebraska - Lincoln

Faculty Publications: Department of

Entomology

Entomology, Department of

1992

Comparison of Chemigated and Aerially-Applied Chlorpyrifos and

Fenvalerate for Control of European Corn Borer (Lepidoptera:

Pyralidae) Larvae

\author{
Thomas J. Weissling \\ University of Nebraska-Lincoln, tweissling2@unl.edu \\ Frank B. Peairs \\ Colorado State University - Fort Collins \\ Stan D. Pilcher \\ Colorado State University - Fort Collins
}

Follow this and additional works at: https://digitalcommons.unl.edu/entomologyfacpub

Part of the Entomology Commons

Weissling, Thomas J.; Peairs, Frank B.; and Pilcher, Stan D., "Comparison of Chemigated and AeriallyApplied Chlorpyrifos and Fenvalerate for Control of European Corn Borer (Lepidoptera: Pyralidae) Larvae" (1992). Faculty Publications: Department of Entomology. 326.

https://digitalcommons.unl.edu/entomologyfacpub/326

This Article is brought to you for free and open access by the Entomology, Department of at DigitalCommons@University of Nebraska - Lincoln. It has been accepted for inclusion in Faculty Publications: Department of Entomology by an authorized administrator of DigitalCommons@University of Nebraska - Lincoln. 


\title{
Comparison of Chemigated and Aerially-Applied Chlorpyrifos and Fenvalerate for Control of European Corn Borer (Lepidoptera: Pyralidae) Larvae
}

\author{
THOMAS J. WEISSLING,${ }^{1}$ FRANK B. PEAIRS, AND STAN D. PILCHER \\ Department of Entomology, Colorado State University, Fort Collins, Colorado 80523
}

\begin{abstract}
J. Econ. Entomol. 85(2): 539-543 (1992)
ABSTRACT Aerial and overhead center-pivot irrigation system (chemigated) applications of chlorpyrifos 4 emulsifiable concentrate (EC) and fenvalerate $2.4 \mathrm{EC}$ significantly reduced numbers of first- and second-generation European corn borer, Ostrinia nubilalis Hübner, larvae in field corn, Zea mays L. The number of first-generation $O$. nubilalis larvae, pupae, or cavities per plant in plots chemigated with chlorpyrifos in 1984 was significantly less than in plots where chlorpyrifos was applied aerially. A similar trend was observed for fenvalerate in 1985. No significant differences among application methods were observed for second-generation $O$. nubilalis treatments. Chlorpyrifos and fenvalerate were effective $O$. nubilalis control agents but efficacy differences between these two insecticides were variable. Corn yields did not vary significantly among application methods.
\end{abstract}

KEY WORDS Insecta, Ostrinia nubilalis, Chemigation, Aerial application

THE APPLication OF agricultural chemicals through irrigation systems (chemigation) was first accomplished in Arkansas during the late 1950s when Bryan \& Thomas (1958) mixed fertilizer with water. This solution was then applied through a sprinkler irrigation system. Insecticides were first applied through overhead center-pivot irrigation systems in Colorado in 1976 by W. Hantsbarger and S. Pilcher (Pilcher \& Peairs 1987). Herbicides (Heikes 1981) and fungicides (Franc et al. 1983) have subsequently been applied through irrigation systems in Colorado.

The advantages and disadvantages of chemigation have been discussed by several authors (Chalfant \& Young 1982; Myers 1985; Threadgill 1981, 1985; Witkowski et al. 1984). Reduced costs are probably the principal factor responsible for the recent increase in chemigation as a pesticide application technique. However, there is little scientific data that compares pest control using chemigation with control by conventional application methods.

Because corn insecticides in Colorado have traditionally been applied by aircraft, replicated side-by-side comparisons of aerial and chemigated applications of chlorpyrifos and fenvalerate were conducted to determine efficacy of control of European corn borer, Ostrinia nubilalis (Hübner), during its first and second generation,

1 Current address: Fort Lauderdale Research and Education Center, University of Florida, Institute of Food and Agricultural Sciences, 3205 College Avenue, Fort Lauderdale, Fla 33314. and to determine resulting yield for each application method-insecticide combination.

\section{Materials and Methods}

The study site was located in the eastern sandhills region of Colorado, in Yuma County. Three center-pivot irrigation systems (circles) were used in 1984 and four were used in 1985. These fields were chosen because of their similarity of soil type, irrigation well capacities, irrigation systems, and cultural practices. Circle sizes ranged from 42.8 to 64.8 ha and each was considered a repetition of a split-plot design. Each circle was randomly divided into an aerially treated and chemigated half, and each half was subdivided into insecticide treated and untreated plots. Differences between the two types of equipment used to apply insecticides limited plot design. Thus, plot dimensions and size were dissimilar between aerially treated and chemigated halves. Aerially treated plots (2) were segments parallel to rows, averaging 5.5 and 6.1 ha in 1984 and 1985 respectively. Chemigated plots (2) were sectors (wedge-shaped) and averaged 6.7 and 5.4 ha in 1984 and 1985, respectively. Because the study was conducted on private land, untreated plot sizes were minimal and randomization was restricted. Untreated check plots in 1984 were one 3-ha segment (parallel to rows) within each aerially treated whole plot, and two 2-ha sectors within each chemigated whole plot (data from each sector were combined before data analysis). In 1985, untreated check plots were two adjoining 2.8-ha sectors that were sit- 
uated between aerially treated and chemigated halves. The sector situated nearest the midline of each circle was assigned the untreated portion of the aerially treated whole plot.

Insecticide treatments were chlorpyrifos (Lorsban 4 emulsifiable concentrate [EC], Dow Chemical Company, Midland, Mich.) applied at $1.12 \mathrm{~kg}$ (AI)/ha, and fenvalerate (Pydrin 2.4EC, Shell Chemical Company, Houston, Tex.) at 0.17 kg (AI)/ha.

The aircraft used to apply insecticide was an Ag Cat G164 A600 with a 12.3-m wingspan, and a $9.85-\mathrm{m}$ spray boom. Twenty whorljet $1 / 8 \mathrm{~B} 10$ nozzles on the spray boom applied a spray volume of 28.4 liters/ha at a pressure of $200 \mathrm{kPa}$, while traveling at $168 \mathrm{~km} / \mathrm{h}$.

The center-pivot irrigation systems (Lockwood electric drive Model 2200, Lockwood Corp., Gering, Nebr.) were equipped with $360^{\circ}$ Senninger impact nozzles and operated at 300-400 $\mathrm{kPa}$ water pressure. Each system delivered 0.83 $\mathrm{cm}$ of water during the 18 -h rotations used during insecticide applications. Irrigation water was pumped from the Ogallala aquifer and had 0.325 MMhos/cm electroconductivity, a $\mathrm{pH}$ of $7.2,7.3$ ppm $\mathrm{NO}_{3}-\mathrm{N}, 0.7 \mathrm{ppm} \mathrm{SO}_{4}-\mathrm{S}, 25.5 \mathrm{ppm} \mathrm{Ca}, 8 \mathrm{ppm}$ $\mathrm{Mg}, 11.5 \mathrm{ppm} \mathrm{Na}, 17.5 \mathrm{ppm} \mathrm{Cl}$, and $369.5 \mathrm{ppm}$ total dissolved solids (analysis by Weld Laboratories, Greeley, Colo.).

Chemigated insecticides were injected through stainless steel one-way injection ports (5 $\mathrm{mm}$ inner diameter) that extended $9.5 \mathrm{~cm}$ into irrigation pipes $(20.3 \mathrm{~cm}$ inner diameter) by either a Hydracone (Interpace Corp., Rochester, N.Y.) Model Rl cone diaphragm pump operating at $8,274 \mathrm{kPa}$ pressure or a Milton Macroy (Milton Roy Company, Hartell Division, Ivyland, Pa.) M212-4-B02 tube diaphragm metering pump injecting at $1,069 \mathrm{kPa}$ pressure. To eliminate recalibration of injector pumps between treatments, solutions were brought to equal volumes with water in a 113-liter nurse tank. Insecticide solutions were agitated manually.

The crop (Zea mays L., 'Os Gold 6882' [Asgrow Seed Company, Plainview, Tex.]) was planted on 3-9 May 1984 and 26 April-6 May 1985 in a sandy loam soil containing $0.567 \%$ organic matter, 7.7 ppm $\mathrm{NO}_{3}-\mathrm{N}, 151.3 \mathrm{ppm} \mathrm{K}, 24.0$ ppm P, 2.0 ppm S, 1.3 ppm Zn, 15.2 ppm Fe, with a $\mathrm{pH}$ of 5.6 (analysis by Ward Laboratories, Kearney, Nebr.). Planting rate was 72,500 seeds per ha with $76.2 \mathrm{~cm}$ between rows.

Timing of insecticide applications was based on $O$. nubilalis egg and larval infestation levels. Within each plot, 10 plants selected at random were carefully inspected for $O$. nubilalis egg masses at weekly intervals before insecticide application. In addition, larval infestation levels were determined before insecticide treatment by the presence of shot-holes (first generation) and by the number of larvae (all instars, second generation) found during weekly dissections of 10 randomly selected plants per plot. First-generation O. nubilalis treatments were applied on 5-6 July 1984 and 3-4 July 1985 to whorl-stage plants (stages V15-V18, Ritchie \& Hanway [1984]). During the first-generation treatment period in 1984, 14.4\% of the plants were infested with $O$. nubilalis eggs, had shot-holes, or both, and the average maximum and minimum temperatures were 30.3 and $16.2^{\circ} \mathrm{C}$. O. nubilalis eggs and shot-holing were observed on $12.4 \%$ of the plants inspected before first-generation treatment in 1985. Maximum and minimum temperatures during the treatment period averaged 34 and $12^{\circ} \mathrm{C}$. Second-generation treatments were applied on 12-13 August 1984 and on 13-16 August 1985 to milk stage corn (R3 stage, Ritchie \& Hanway [1984]). Accumulated infestations of $O$. nubilalis eggs and larvae before application of second-generation treatments were 12.0 and $9.8 \%$ in 1984 and 1985, respectively. Averaged maximum and minimum temperatures during second generation application were 33.9 and $16.4^{\circ} \mathrm{C}$ in 1984 , and 27.5 and $14.2^{\circ} \mathrm{C}$ in 1985 .

Efficacy of first-generation treatment was determined by selecting $10 \mathrm{O}$. nubilalis-damaged plants at four (1984) and two (1985) random sites per plot. Damaged plants were selected to ensure that plants were infested with $O$. nubilalis larvae at the time of insecticide application. These plants were split lengthwise from the tassel to the first root node and the number of cavities (any size), pupae, and larvae (third to fifth instars) were recorded. Evaluations for control of first-generation $O$. nubilalis were made on 27 and 30 July 1984, and on 17-18 July 1985.

Evaluation of second-generation $O$. nubilalis control differed from the methods used during the first generation in that 10 randomly chosen plants rather than damaged plants were split from tassel to the first root node, as was the ear shank. In addition, only $O$. nubilalis larvae (third to fifth instars) were recorded. Randomly selected plants were used to evaluate secondgeneration $O$. nubilalis treatments because presence of visual damage would not ensure that plants were infested before insecticide application (i.e., damage observed may have been caused by first-generation larvae). Treatment evaluations were made on 15-16 September 1984, and on 27-28 August 1985.

To determine yield, ears from all plants in 0.0004 ha $(5.34$ row-m) were collected at four (25 October 1984) and two (15 October 1985) randomly chosen locations per plot, and were weighed in the field. From each sample, a random four-ear subsample was saved and later weighed and shelled. The shelled grain was then weighed and percent moisture was recorded. Weights were adjusted to $15.5 \%$ moisture for the entire sample and data were converted to metric tons per hectare. Yield was not determined in 
Table 1. Comparison of two insecticides applied aerially and through overhead center-pivot irrigation systems (chemigated) for control of European corn borer larvae

\begin{tabular}{lccccc}
\hline \hline \multirow{2}{*}{$\begin{array}{c}\text { Subplot } \\
\text { treatment }\end{array}$} & \multicolumn{4}{c}{ No. per plant, $\bar{x} \pm$ SEM } \\
\cline { 2 - 5 } & \multicolumn{2}{c}{ First generation $^{b}$} & & \multicolumn{2}{c}{ Second generation } \\
\cline { 2 - 5 } & Aerial & Chemigated & & Aerial & Chemigated $^{c}$ \\
\hline & & & 1984 & & \\
Untreated & $1.8 \pm 0.2$ & $1.5 \pm 0.3$ & & $2.4 \pm 0.2$ & $2.7 \pm 0.4$ \\
Chlorpyrifos & $1.2 \pm 0.2$ & $0.2 \pm 0.1$ & & $2.2 \pm 0.3$ & $1.0 \pm 0.1$ \\
Fenvalerate & $0.8 \pm 0.1$ & $0.7 \pm 0.1$ & & $0.9 \pm 0.1$ & $0.8 \pm 0.2$ \\
& & & 1985 & & \\
Untreated & $1.4 \pm 0.2$ & $1.3 \pm 0.1$ & & $0.1 \pm 0.1$ & $0.2 \pm 0.1$ \\
Chlorpyrifos & $0.7 \pm 0.1$ & $0.4 \pm 0.1$ & & $0.2 \pm 0.1$ & $0.1 \pm 0.1$ \\
Fenvalerate & $1.1 \pm 0.1$ & $0.6 \pm 0.1$ & & $0.1 \pm 0.1$ & $0.3 \pm 0.1$ \\
\hline
\end{tabular}

Least significant difference values (mean no. per plant) at $P=0.05$ for means within a column (application method and year): first generation 1984, 0.9;1985, 0.4. Second generation 1984, 1.2. For means within a row (differences between application method within a treatment): first generation $1984,0.7 ; 1985,0.4$; second generation $1984,1.6$.

${ }^{a}$ Chlorpyrifos $4 \mathrm{EC}$ and fenvalerate $2.4 \mathrm{EC}$ were applied at 1.12 and $0.17 \mathrm{~kg}(\mathrm{AI}) / \mathrm{ha}$, respectively.

${ }^{b}$ Third to fifth instars, pupae, and cavities found in corn stalks during plant dissections $[n=120(1984)$, $n=80$ (1985)].

$c$ Third to fifth instars found in corn stalks during plant dissection $[n=120(1984), n=80(1985)]$.

untreated portions of chemigated main plots in 1984.

Statistical Analysis. All data were subjected to square root $(x+0.5)$ transformation and were analyzed as a split-plot design by analysis of variance using the Statistical Analysis System general linear models procedure (SAS Institute 1985). Variation among replications and mainplot (application method) treatments was tested over the block-by-application method interaction. Subplot (insecticide and untreated check) treatment effects and remaining interactions were tested over the residual error mean square. Orthogonal contrasts (SAS Institute 1985) were used to test for differences among subplot treatments and included untreated check versus insecticide treated and chlorpyrifos versus fenvalerate. Differences were considered significant at $P<0.05$. Differences between subplot treatment means within an application method, as well as differences between application methods within a subplot treatment, were determined by calculating least significant difference values $(t=0.05$ [Little \& Hills 1975]). Untransformed means are presented.

\section{Results and Discussion}

First-Generation $\boldsymbol{O}$. nubilalis. First-generation O. nubilalis infestation levels in untreated plots following application of insecticides averaged 1.7 and 1.4 larvae, pupae, and cavities per plant in 1984 and 1985, respectively (Table 1). Analyses indicated that significant differences occurred among application methods (1984: $F=$ 155.37; $\mathrm{df}=1,2 ; P<0.01 .1985: F=62.86$; $\mathrm{df}=$ $1,3 ; P<0.01)$ and treatments $(1984: F=25.65$; $\mathrm{df}=2,58 ; P<0.01 .1985: F=31.79 ; \mathrm{df}=2,30$; $P<0.01$ ). In addition, a significant application method $x$ treatment interaction was observed in $1984(F=7.97 ; \mathrm{df}=2,58 ; P<0.01)$.
Significantly fewer first-generation O. nubilalis larvae, pupae, and cavities were detected in chemigated than in aerially treated plots after insecticide application (mean larvae, pupae, and cavities per plant in 1984: aerially-applied, 1.2; chemigated, 0.8. In 1985: aerially-applied, 1.1; chemigated, 0.7). In practice, however, aerially applied carbofuran granules rather than aerially applied liquids would be the standard alternative to chemigated liquids. Average 1980-1984 first-generation $O$. nubilalis control with aerially applied carbofuran granules in eastern Colorado studies was $88 \%$ (Pilcher \& Peairs 1987). In this study, aerially applied liquids averaged only $38 \%$ control.

Orthogonal contrasts indicated that the number of first-generation $O$. nubilalis larvae, pupae, and cavities in untreated check plots was significantly greater than in insecticide treated plots (mean larvae, pupae, and cavities per plant in 1984: untreated, 1.7; insecticide treated, 0.7. In 1985: untreated, 1.4 ; insecticide treated, 0.7 [1984: $F=50.20 ; \mathrm{df}=1,58 ; P<0.01 .1985: F=$ $55.49 ; \mathrm{df}=1,30 ; P<0.01])$. Statistical differences between first generation $O$. nubilalis densities in plots treated with chlorpyrifos and fenvalerate were observed only in 1985 (mean larvae, pupae, and cavities per plant: chlorpyrifos, 0.6 ; fenvalerate, $0.9[F=8.09 ; \mathrm{df}=1,30 ; P<$ $0.01]$ ).

In 1984, first-generation O. nubilalis densities in untreated portions of aerially treated main plots were significantly greater than in plots where fenvalerate was applied aerially (Table 1). In 1985 , the number of $O$. nubilalis larvae, pupae, and cavities in plots treated with aerially applied chlorpyrifos were significantly less than in the untreated check. Within chemigated main plots in 1984, first-generation O. nubilalis densities in plots treated with chlorpyrifos were significantly less than in untreated plots (Table 1 ). 
In 1985, first-generation O. nubilalis densities in plots chemigated with chlorpyrifos and fenvalerate were significantly less than in untreated plots. Differences between levels of control with chlorpyrifos and fenvalerate between main plots may have contributed to the significant application method $x$ treatment interaction observed in 1984.

In 1984, chlorpyrifos provided greater control of first-generation $O$. nubilalis when chemigated than when applied aerially (Table 1). In 1985, fenvalerate was more effective at reducing firstgeneration $O$. nubilalis when applied through the pivot than when applied aerially.

Second-Generation $O$. nubilalis. In 1984, an average of 2.6 second-generation $O$. nubilalis larvae were observed per plant in untreated plots after insecticide application but only 0.2 larvae per plant were found in untreated plots in 1985 (Table 1). Egg mass counts were similar in both years, so larval survivorship must have been lower in 1985.

Statistical differences were observed among treatments in $1984(F=36.3 ; \mathrm{df}=2,58 ; P<0.01)$ as was a significant application method $\times$ treatment interaction $(F=6.73 ; \mathrm{df}=2,58 ; P<0.01$ ). Because of low second-generation $O$. nubilalis infestation levels observed after insecticide application in 1985, treatment effects could not be substantiated.

Orthogonal contrasts indicated that the number of second-generation $O$. nubilalis larvae in untreated plots in 1984 was significantly greater than in insecticide treated plots (mean larvae per plant: untreated, 2.6; insecticide treated, 1.2 $[F=54.3 ; \mathrm{df}=1,58 ; P<0.01])$. In addition, the number of second-generation $O$. nubilalis larvae in fenvalerate treated plots was significantly less than in plots treated with chlorpyrifos (mean larvae per plant: chlorpyrifos, 1.6 ; fenvalerate, 0.8 $[F=18.3 ; \mathrm{df}=1,58 ; P<0.01]$ ).

Within aerially treated main plots in 1984, second-generation $O$. nubilalis larval densities in plots treated with fenvalerate were significantly less than in plots treated with chlorpyrifos or left untreated (Table 1). The number of secondgeneration $O$. nubilalis larvae in plots chemigated with chlorpyrifos and fenvalerate was significantly less than in the untreated portions of chemigated main plots. Differences between second-generation $O$. nubilalis control with chlorpyrifos applied aerially and chemigated may have led to the significant application method $x$ insecticide interaction observed in 1984.

Yield. Yields varied considerably between plots (Table 2). However, significant yield differences were observed only among subplot treatments in 1985 ( $F=7.66$; df $=2,30 ; P<0.01$ ).

Orthogonal contrasts indicated that plots treated with insecticide in 1985 yielded significantly more grain than untreated plots (mean
Table 2. A comparison of yields in plots treated with two insecticides applied aerially and through overhead center-pivot irrigation systems (chemigated) for control of European corn borer larvae

\begin{tabular}{|c|c|c|}
\hline \multirow{2}{*}{$\begin{array}{l}\text { Subplot } \\
\text { treatment }^{b}\end{array}$} & \multicolumn{2}{|c|}{$\begin{array}{c}\text { Yield (metric tons per ha), } \\
\bar{x} \pm \mathrm{SEM}^{a}\end{array}$} \\
\hline & Aerial & Chemigated \\
\hline & \multicolumn{2}{|c|}{1984} \\
\hline $\begin{array}{l}\text { Untreated } \\
\text { Chlorpyrifos } \\
\text { Fenvalerate }\end{array}$ & $\begin{array}{l}11.7 \pm 0.4 \\
13.0 \pm 0.3 \\
12.0 \pm 0.6\end{array}$ & $\begin{array}{c}\text { nd } \\
12.1 \pm 0.5 \\
12.6 \pm 0.5\end{array}$ \\
\hline & \multicolumn{2}{|c|}{1985} \\
\hline $\begin{array}{l}\text { Untreated } \\
\text { Chlorpyrifos } \\
\text { Fenvalerate }\end{array}$ & $\begin{array}{l}10.7 \pm 0.7 \\
11.8 \pm 0.4 \\
11.4 \pm 0.7\end{array}$ & $\begin{array}{l}11.3 \pm 0.3 \\
13.3 \pm 0.4 \\
12.8 \pm 0.3\end{array}$ \\
\hline
\end{tabular}

Least significant difference values (Mton/ha) at $P=0.05$ for means within a column (application method and year): 1984, $2.4 ; 1985,1.7$. nd, not determined.

${ }^{a}$ Yields determined from four-ear subsamples at four (1984) and two (1985) random locations per plot $(n=12,1984 ; n=8$, 1985).

${ }^{b}$ Chlorpyrifos $4 \mathrm{EC}$ and fenvalerate $2.4 \mathrm{EC}$ were applied at 1.12 and $0.17 \mathrm{~kg}(\mathrm{AI}) / \mathrm{ha}$, respectively.

metric tons per hectare: untreated check, 11.0; insecticide treated, $12.3,[F=14.05 ; \mathrm{df}=1,30$; $P<0.01]$ )

No statistical differences in yield were observed among subplot treatments in 1984 within either application method. However, plots chemigated with chlorpyrifos in 1985 yielded significantly more grain than the untreated portions of chemigated main plots (Table 2).

Even though $O$. nubilalis pressure during this study was relatively light, yields in chemigated plots were expected to be higher than in aerially treated plots because of differences in firstgeneration $O$. nubilalis control among main plots treated with chlorpyrifos in 1984 and fenvalerate in 1985. Possible yield differences among application methods and insecticide treatments may have been negated by the small sample size used to determine yield.

Conclusion. In view of the questionable future of carbofuran granules (the standard formulation used for management of insect pests in whorlstage field corn in eastern Colorado), chemigation is becoming an increasingly important insecticide application technique. Data presented in this study suggest that chemigation is a viable alternative to the aerial application of liquid insecticides for control of $O$. nubilalis larvae. Chlorpyrifos and fenvalerate were effective $O$. nubilalis control agents when chemigated and efficacy differences between these insecticides appeared negligible. Although yields varied considerably, the data further suggest that insecticide application using either method limits grain loss from pest feeding. 


\section{Acknowledgment}

We are grateful to the Gleason Dryden family for allowing us to use their land. We thank Steve Bottecher, Les Brokaw, Kevin Fehringer, Dave Horton, Fred Judson, Wendy Meyer, Jeffery Rudolf, and Dave Thompson for their assistance. Funding for this study was provided by the Western Regional Pesticide Impact Assessment Program, Colorado State University Agricultural Experiment Station Project 053, Dow and Shell Chemical companies, and the Environmental Protection Agency.

\section{References Cited}

Bryan, B. B. \& E. L. Thomas, Jr. 1958. Distribution of fertilizer materials applied through sprinkler irrigation systems. Ark. Agric. Exp. Stn. Bull. 598.

Chalfant, R. B. \& J. R. Young. 1982. Chemigation, or application of insecticide through overhead sprinkler irrigation systems, to manage insect pests infesting vegetable and agronomic crops. J. Econ. Entomol. 75: 237-241.

Franc, G. D., E. C. Nnodu, M. D. Harrison \& A. J. Sadler. 1983. Evaluation of sprinkler application of fungicides for control of Potato early blight in Colorado. Am. Potato J. 63: 631-643.

Heikes, H. E. 1981. Proceedings, National Symposium on Chemigation. Rural Development Center, Tifton, $\mathrm{Ga}$.

Little, T. M. \& F. J. Hills. 1975. Statistical methods in agricultural research, 2 nd ed. University of Califonia, Davis.
Myers, R. G. 1985. Center-pivots and chemigation. Proceedings, Fifth National Symposium of Chemigation. Rural Development Center, Tifton, Ga.

Pilcher, S. D. \& F. B. Peairs. 1987. Extension's experience with insectigation in Colorado: equipment, oil additive, and control of European cornborer and Western bean cutworm in field corn. In J. R. Young [ed.], Proceedings of the National Entomological Society Meetings, Section F Conference: Chemigation of Insecticides as an Application Technique for Insect Control, San Antonio, Texas. December 1984.

Ritchie, S. W. \& J. J. Hanway. 1984. How a corn plant develops. Special Report No. 48, Iowa State University of Science and Technology, Cooperative Extension Service. Ames, Iowa.

SAS Institute. 1985. SAS users' guide: statistics, version 5 ed. SAS Institute, Cary, N.C.

Threadgill, E. D. 1981. Why chemigate? Proceedings, National Symposium on Chemigation. Rural Development Center, Tifton, Ga.

1985. Current status and future of chemigation. Proceedings, Fifth National Symposium on Chemigation. Rural Development Center, Tifton, Ga.

Witkowski, J. F., D. R. Hay, D. Barber, T. Dorn \& R. Gold. 1984. Applying insecticides through center-pivots. University of Nebraska, NebGuide G84-703.

Received for publication 16 March 1990; accepted 13 November 1991. 